ARTICLE

Received 1 Dec 2016 | Accepted 14 Mar 2017 | Published 11 Apr 2017

\title{
Discourse as virtue ethics: Muslim women in the American Southwest
}

Maisa C. Taha ${ }^{1}$

ABSTRACT This article examines naturally occurring speech among participants in a young women's halaqa, or study circle, at a mosque in the southwest United States to detail how "tactics of linguistic objectification" provide anchor points for ethical negotiations of difference. By focusing on linguistic micro-practices, including codeswitching and mock "foreign" accents, this paper brings a linguistic anthropological approach to bear upon this inquiry into discourse as a mode of phronesis. It is argued that, during informal conversation, core members of this group of largely second-generation immigrant women highlighted features of non-native English speech to monitor, examine, and mediate their own and their families' hypervisibility as U.S. Muslims. As policy and public opinion paint a picture of Muslims as an existential threat to the west, these women's language use, narratives and laughter act as ingroup responses to social scrutiny that makes acknowledgement and normalization of Muslim difference obligatory. This article is published as part of a collection on discourse studies.

\footnotetext{
${ }^{1}$ Montclair State University, Montclair, NJ, USA Correspondence: (e-mail: taham@montclair.edu)
} 


\section{Introduction}

eriodically, the U.S. media highlight efforts by Muslim Americans to dispel the fear and misunderstanding that has grown up around their communities in the wake of the September 11 attacks, the rise of ISIS, and more recent terrorist attacks in the west. In response to then-candidate Donald Trump's campaign pledge to ban Muslims from entering the country, for example, a Massachusetts woman and her husband set up an "Ask a Muslim" table outside of a local library (NPR Staff, 2015). Offering free donuts and coffee, they engaged passersby in conversation-a bid for transparency that also sought to shift public perceptions toward seeing Muslims as friendly, approachable, and in a word, innocuous. Such grassroots responses from individuals seek to humanize and personalize the public face of Islam against a growing tide of Islamophobic rhetoric (backed now by radically xenophobic executive orders).

But it would be a mistake to assume that efforts to normalize Muslim identity occurred or were meaningful only in meetings between Muslims and non-Muslims. In this article, I turn to data collected during fieldwork with young Muslim American women in 2007-a rough midpoint between 9/11 and the current intensification of anti-Muslim sentiment-to show how efforts to monitor, normalize, and define Muslim difference constitute a group-internal concern, as well. I argue that particularly among youth of immigrant heritage, contemporary Muslim subjectivity emerges at the intersection between claiming difference and recognizing the fear and suspicion to which that difference will likely be subjected. My focus is on naturally occurring speech among participants in halaqas, or study circles, at a mosque in the southwest United States, and how their talk yielded a multifaceted, but linguistically anchored, discourse of self-conscious difference.

Here, discourse refers to speakers' collaborative articulation of sensibilities and subject positions. I build from a broadly pragmatic conceptualization of the term that encompasses the interactional and ethical dimensions of utterances as constitutive of social realities and relationships, particularly in situations of hierarchical status or privilege (Foucault, 1972; Gaudio, 2009; Angermuller, 2013). For halaqa attendees, discourse involved scrutiny of one's own and one's loved ones' behavior or appearance, especially when the gaze of the dominant society was evident. In this sense, it was also a working-through of how difference could safely be claimed or whether it required reframing for the sake of defusing fear or resolving misunderstanding. The moments that interest me most are those in which participants' conversation turned away from the chosen lesson for the night, which included teachings on topics such as repentance and modesty, and moved into informal chatting and storytelling. While lessons concerned explicit discussion of how to uphold and embody Muslim virtues on a daily basis, informal conversation revealed the subtle ways in which these young women forged a sense of vigilant and virtuous subjectivity through reflexive examination of their own hypervisibility.

Most notably among core halaqa participants, who included college-aged women of Arab and South Asian backgrounds, linguistic performance and meta-linguistic commentary provided key nodes around which this discursive monitoring took place. For those who spoke Arabic, codeswitching was a way to claim difference as well as a source of occasional embarrassment. Others imitated their fathers' Arabic- and Urdu-accented English to humorous effect, drawing attention to their own positioning as generationally savvy-but socially vulnerable-mediators of this marker of foreignness.

Using a linguistic anthropological approach to consider these micro-practices in a wider context of political tension, my contribution to this thematic issue is to draw attention to the role of identifiable linguistic features and strategies in the ongoing creation of these complex subject positions. By this I mean that I apply an understanding of the indexical function of language itself in semiotically weighting nodes of identitarian or ideological meaning-making (Silverstein, 1976; Agha, 2007). I also draw from developments in ethnographic discourse analysis (Wortham and Reyes, 2015) and theorization of communities of practice (Eckert and McConnell-Ginet, 1992) to cast subjectivity as emergent from face-to-face interaction. Finally, I call for discourse scholars, particularly those devoted to ethnographic research, to consider the phronetic dimensions of language-in-use: the means by which linguistic practices themselves mediate how social values propel interaction and shape subjects' relationships to power. In this, I seek a union of insight between linguistic anthropological work which illuminates the ethical and moral capacities of linguistic form, function, and ideology (for example, Hill, 1995, 2008) and attention in ethnographic and applied social science to the Aristotelian notion of phronesis (Flyvbjerg, 2001; Jouili, 2015). Since phronesis is "practical wisdom", born of experience in the world and cultivating of a sense of responsibility both to self and to society (Flyvbjerg, 2001, 55-57), people's display and assessment of linguistic performance provides a rich point for analyzing how they negotiate the aesthetics and ethics of virtuous subjectivity-particularly when virtue is under suspicion. This is my objective for the remainder of this article. Following a description of halaqa meetings and a review of relevant literature, I present analysis of three audio recorded data excerpts to advance these points.

\section{The girls' halaqa}

"Girls" halaqas, as participants called them, took place every Friday after evening prayer in spare meeting rooms in a mosque I call Desert Masjid. When the only space available was a children's classroom, the twenty-or-so attendees, mostly college students between the ages of 18 and 23, moved tables aside and sat in a circle, shoulder to shoulder on tiny chairs, knees folded up toward their chins. What participants lacked in terms of reliable space at the mosque they made up for in consistent attendance and enthusiastic, wide-ranging discussions of Islamic scripture, family, and the pressures of university life. Most took demanding courses of study in pre-medicine, pre-pharmacy, the sciences, or engineering. Like other Muslim students on campus, they tended to sign up for classes in Arabic language and history for their obligatory humanities credits. In this way, their friendships stemmed not only from weekly encounters at the mosque but were maintained throughout the week and often capped off by a dinner out at a Middle Eastern restaurant on the weekends.

Unlike the older women (khalas, or "aunties," within the extended kinship of the mosque) who held Friday halaqas in Arabic, young women conducted theirs primarily in English, making it possible for members of various backgrounds to participate. The seven core halaqa attendees included women whose parents were first-generation Iraqi, Libyan, Egyptian, Lebanese and Pakistani immigrants. Newer participants included recent American converts to Islam and women of Afghan, Malaysian, and Mexican heritage. With few exceptions, all spoke natively-fluent American English, and all were at least conversationally adept in their family's native languages. Arabic, both conversational and in sacred formulae, played a prominent role in halaqa discussions, not incidentally because most participants identified as Arab or Arab American, and the language served as a key index of authenticity. Pakistani Urdu-accented English, as I discuss toward the end of the article, played a prominent role in one participant's humorous narratives about her father. 
Halaqas lasted between two and three hours, often disbanding only when the groundskeeper came to announce that he was closing the building for the night. Each meeting was loosely organized into two parts. The first consisted of a prepared presentation on a topic of interest within Islam, delivered by a volunteer in the group who had offered to research it. Topics included patience, repentance, modesty, and giving thanks to Allah. Presentations took the form of lessons, drawing on examples from the presenters' and others' lives, as well as verses from the Qur'an. Presenters researched their topics online or got help from family members to compile several instructional stories from scripture, scholarly interpretations, and hadith, accounts of the prophet Muhammad's sayings and actions that provide daily guidance for Muslims. Presentations were punctuated by presenters' apologies for not having more time to prepareschool work having kept them busy and up late-or for not knowing more about their topic. In this way, presentations became opportunities for collaborative learning, with group members interjecting questions, suggestions, and instructive stories of their own.

Such activity can be understood as part of the growing worldwide Muslim practice of $d a^{i} w a$, whereby believers are to urge one another to engage Islamically sanctioned notions of virtue and maintain pious living (Mahmood, 2005, p. 57). Within the diverse group of young women at Desert Masjid, discussions of "correct" conduct often revealed points of cultural ambivalence, however. During a discussion of modesty, for example, Sara -one of the seven core participants but one of only two Pakistani Americans in the group-giggled as she wondered aloud whether she was immodest for wearing short-sleeved shirts. "In my culture, it's modest if you have short sleeves and your pants are at least below the knee", she laughed, "[But] the funniest thing I found out was that the burka came from Pakistan. [...] I thought that was so ironic. There are ladies walking around in see-through clothes in Pakistan!"

"Islamically, you don't have to dress that way," Nerine responded, referring to the burka. Her peers often turned to her for authoritative interpretations of pious conduct. "In Islam, you're not supposed to take it too literally, to where you don't show anything and you're just some cloth moving around!"

"It's different for someone who wasn't Muslim to begin with," Dana piped up. She was an Anglo-American convert who often saw things differently from her peers. "To me, even wearing long sleeves all the time is really strange. Before, I wore normal skirts that girls wore on campus, and tube tops. It's so comfortable when it's hot out! So I'm like, can't I just wear my skirt?"

"You can, with pants!" Sara said. "Make sure it's not the fluttery kind! Wait, why didn't I think of that?"

Discussions such as these revealed how the contours of local Islamic living were shaped by wide-ranging cultural expectations and conditioning. The sense that religious virtue was forged through awareness and resistance to challenges lay at the core of halaqa talk. As a visitor to the group stated once, "We can get more blessings from being Muslims in a non-Muslim countrybecause it's harder to be a Muslim here". This sentiment captures the ways in which participants' formulations of virtue and vulnerability, outside the framework of halaqa lessons, emerged at meeting points with non-Muslim sensibilities.

The second part of the halaqa consisted of announcements, event planning, and unstructured talk. The free-wheeling conversation included jokes, teasing, and pleas by those present for Sara, a gifted and entertaining storyteller, to "make us laugh". Laughter often accompanied what I call tactics of linguistic objectification-use of and reflection upon elements of "foreign" linguistic performances in an English-dominant surround. As an index of Muslim difference, language itself was an object of scrutiny and assessment, allowing participants to claim, reframe, or ultimately normalize their own presence as a non-threat to others. I argue that out of such linguistic practice a phronetic basis for enacting virtue in the world emerged: language marked aesthetically unique speaker sensibilities as the products of lived experience and promoted ethically responsive stances toward the potentially dangerous or misinformed "othering" of speakers. Informal halaqa talk provided moments in which participants worked out with one another how to define their difference within the wider world, and their conversations provided evidence of an especially complex subject positioning, forged at the nexus between self and other, and integrity and suspicion.

So, in distinct but complementary ways, these two parts of halaqa meetings promoted virtuous self-awareness and selfmonitoring. On the one hand, participants' active concern for "right" living fostered lively discussion over how to operationalize religious teachings in everyday life. On the other hand, informal conversations, storytelling, and laughter provided halaqa-goers with channels for elaborating and sanctioning virtuous sensibilities that went beyond the purview of religious teachings. I focus on the latter in the analysis below.

\section{Literature review}

One of the classic Aristotelian virtues, phronesis provides a way to view social practices not merely as rational-strategic action, but also in terms of peoples' interested and value-laden deliberation processes. As Flyvbjerg (2001; see also Flyvbjerg et al., 2012) has argued, a full understanding of phronesis extends beyond mere "prudence" and must be considered in terms of actors' relationships to power structures, including access to resources and influence, and the hegemonic discourses that support these. Phronesis is action oriented toward the good of self and society, but it is delimited by motivating values and contextually relevant relations of inequality or privilege. Jouili's (2015) ethnographic work with European Muslim women has highlighted phronesis as arising from moments of conflict, specifically collisions between western liberal and religious value systems. For women whose overriding concern is to do things "right" while living in a non-Muslim context, mere religious adherence is not enough; but neither is single-minded Foucauldian "discipline" adequate to apprehend their strategies for navigating contrasting scales of virtue, both religious and material. Indeed, the important point is that phronesis makes salutary action possible only as a result of experience and socially savvy reflexivity. As Goodale (2012) has put it, phronesis rests upon "a willingness to self-evaluate action [...] in terms of both prevailing social norms and desired ends" (p. 470). It is just this sort of practice that halaqa participants engaged in voicing and evaluating difference through linguistic misencounters with the dominant society.

Accounts of Muslims in the United States have emphasized the extent to which believers feel caught between two distinct ways of life. Mir (2014), for example, examines how Muslim young women try but ultimately fail at feeling "normal" within the hedonistic culture of American university life. Wang (2014) finds that youth and their parents are engaged in a continual struggle to reconcile two sides of themselves: "the American self and the Muslim self" (p. 125). The dualism of these formulations speaks to entrenched folk notions of identitarian purism. The presupposition that ethno-religious or national hybridity makes for confused or incoherent living calls up ideas of racial and linguistic purity connected to the founding of the nation-state. Still, such literature also promotes analytic reflexivity, prompting researchers and readers to question the universality of secular liberal norms (Ahmed, 1992; Mahmood, 2005) and answering 
homogenizing stereotypes with countervailing evidence of multiple viewpoints, experiences, and behaviors. This has been especially true in treatments of Muslim women's lives in the United States and elsewhere (for example, Nafisi, 2003; Satrapi, 2003; see also Hammer, 2012).

Hill (2008) has explained this kind of effort as driven by a common referentialist language ideology, which holds that stereotypes, containing untrue language, are best combatted by presenting "true" counter-evidence. Ironically, debunking also sustains and recirculates stereotypes, and indeed, Muslim Americans find themselves locked into referentialist chains of discourse about their lives and loyalties (see the "Ask a Muslim" example which opened this article). By attending below to naturally occurring in-group speech rather than metacommentary solicited through interviews, I intend to show how one community of young Muslim American women worked together to position themselves as legitimate and virtuous social actors in relation to the assumptions of non-Muslims.

I situate my approach within a prominent thread of linguistic anthropological work focusing on first- and second-generation immigrant youth and language use (Zentella, 1997; González, 2005; García-Sánchez, 2015). This research, inspired by work on youth identities, learning, and community formation more generally (Eckert, 1989; Goodwin, 2006; Bucholtz, 2011), emphasizes how young people negotiate majoritarian, marginal, and moment-to-moment identities through language and embodied action. Mendoza-Denton's (2008, 2016) research with Latina gang members in northern California exemplifies how larger geopolitical polarities can be reproduced through speakers' linguistic, sartorial, and behavioral stances, creating actionable divides between "American" (English-speaking) and presumably "non-American" (English-limited or non-English speaking) identities. Tetreault's (2015) research with North African youth in Parisian banlieues shows that through face-toface repertoires including teasing and insults, her participants voice and reframe French denigration of Arab Muslims along with their own loyalty to cultural and kinship norms. Such findings make clear how young people from immigrant families use language to negotiate their positioning within the dominant society.

Related to this, studies of "mock" speech-Mock Spanish (Hill, 1993, 2008), Mock Ebonics (Ronkin and Karn, 1999), and Mock Asian (Chun, 2004), as they have been called-have made it possible to unpack the covert "othering" that even non-serious speech can perform. I use the foundation laid by this work to argue that core halaqa members' mock Arabic and PakistaniUrdu accents, considered in the latter part of the analysis below, help construct their status as normalizers of Muslim difference. In this case, it is their ability to imitate their fathers' accents to comic effect that reproduces foreignness through language as a sign of (sometimes threatening) ethno-religious difference. It is also their ability to move in and out of these voicings which enable their positioning as self-aware, virtuous mediators of that difference. As Chun (2004) has shown, the use of mocking repertoires by second-generation, bicultural and bilingual speakers offers potential for critical, but ambivalent, resistance to dominant ideologies of difference. While such linguistic mockery may be morally authorized, given the speaker's insider-outsider status, it also highlights entrenched ideologies of linguistic, ethno-racial and cultural conformity.

Meanwhile, scholars including Mahmood (2005) and Fader (2009) have documented the practices of revivalist Muslim and Hasidic Jewish women, respectively, pointing out how virtuous living can be enacted through religious observance and daily activity, including social time with family and one another, and often in a morally instructive frame of interaction. Fader details how the use of variously marked linguistic competencies (for example, Hasidic English versus Hasidic Yiddish) mediates her participants' gendered and ethnoreligious sensibilities-a connection that informs my own examination of halaqa attendees' use of mock accent, non-English phonology and phrasing, and metacommentary upon both. Together, these comprise what I am calling tactics of linguistic objectification. As a salient feature of sensibility- and subjectivity-producing discourse, these tactics provide a focal point for halaqa participants' collaborative phronetic engagement, where the integrity of the speaking self and its recognition as "different" inspired reflexive monitoring and reframing.

\section{Conspicuous but savvy: tactics of linguistic objectification}

Tactics of linguistic objectification involve indexically rich assertions about belonging that turn linguistic tokens and styles, as well as claims to cultural knowledge and ethno-racial/-religious experience, into material for a situated practice of sociopolitical savvy and aesthetic integrity. By aesthetic integrity I refer to core halaqa participants' various commitments to non-English (Arabic or Urdu) phonology and claims to markers of ethno-religious and/or racialized difference vis-a-vis dominant white American society. That is, speakers marked their own "foreignness" sonically, through codeswitching and mock accent, as well as visually, by drawing attention to skin tone and to the ethnoracializing power of religious icons like the hijab. These nodes of discursive engagement emphasized otherness and anticipated or controlled for outsiders' responses to it. The very tokens of difference that made core participants vulnerable to critique, misunderstanding, or embarrassment were the bases for claims to a uniquely wrought understanding of difference-how to enact it and see it-that even marginal members of the same halaqa did not share.

In the following analysis, I make reference to halaqa participants" "ethno-racial," "ethno-religious," and simply "racial" or "racialized" differences. These somewhat interchangeable usages stem from an understanding of race in the U.S. context, which has been constructed historically through policy or popular opinion as a catch-all for those deemed to fall outside the shifting norm of whiteness. While skin color and phenotype remain important folk markers of race, it is also true that religion and language have constituted criteria for racializing (and criminalizing) minority groups who at other times may have been subsumed under a more innocuous understanding of "ethnicity" (Goodman et al., 2012). This has certainly been the case for South Asians and Arabs in the United States (Bayoumi, 2008). And one has only to read recent news headlines to understand that Muslims in the United States have undergone a process of racialization that draws together notions of cultural, linguistic, phenotypic and religious otherness (Lippi-Green, 2012; Alim, 2016). Such treatments deal directly with the brokering of citizenship rights within a diverse society.

For halaqa participants, legal citizenship status varied, from those who were born in the United States to others who awaited permanent residency. Cultural citizenship (see Gaudio, 2009), however, rested along intersecting lines of linguistic and ethicomoral practice through their vigilance over aesthetic performance and capacity for cultural mediation. Discourse itself, then, constituted a virtuous practice elaborated within the space of the halaqa and responsive to a dual imperative: (i) to remain politically self-aware and (ii) to defuse the perceived threat of Muslim presence in the United States. Each of the three excerpts below comes from three months of participant observation with halaqa members and more than 24 hours of audio-recorded conversation. 


\section{Linguistic exposure: slips into Arabic}

Among Muslims, the use of "god phrases" serves to remind speakers to maintain a religious bearing in everyday life. During halaqa lessons, presenters studiously employed praising formulae such as salla allahu alayhi wa sallam (may Allah's blessings and peace be upon him) when mentioning the Prophet Muhammad and subhananu wa ta'ala (the most glorified, the most high) when mentioning Allah. While such phrases have acquired ideological value within the expanding Islamic revival as indications of a pious disposition-particularly if a speaker has a large repertoire of such phrases and uses them prolificallymore common formulae such as insha allah (God willing) or alhamdulillah (praise God) can also be understood as normal parts of everyday speech (Gaudio, 2009; Welji, 2012). For Arabicspeaking halaqa attendees, such phrases served as indexes of both piety and bilingual fluency. For example, as Nerine discussed plans for an upcoming bridal party, someone asked, "When is it? On the twenty-fourth?" Nerine replied, "Yes, insha allah. And I'm asking everyone to bring ten dollars to cover costs. If you can give more, think about it cuz some people really can't afford it, and others won't pay it. I wish we didn't have to ask but that's how life is and 'hamdulillah. I'm also asking the khalas [aunties] to bring a small appetizer. It's not a problem insha allah."

When used in dialogue between speakers, these phrases constitute second terms in adjacency pairs (Atkinson and Heritage, 1984), their automaticity akin to the English "Fine" in response to "How are you?" Indeed, such usage was commonplace at the halaqa and at Desert Masjid generally, but as a conversation between Mona, Nur, and Nerine suggested, it merited monitoring outside. The first two women had been commiserating about the stress of school and the difficulty of a recent organic chemistry exam. "I'm glad we share that!" Mona said, laughing. "We share a lotta stuff, man!" Nur said jovially. "I mean, we cry about the same things, and-" "Yeah, and stress out too much," Mona agreed. "Maybe we're the same person and we don't know it!" Their exchange was filled with consensus building collaboration and continued as follows, with Nur relaying episodes when she "slipped" into Arabic with her instructors. Nerine intervenes in line 24, and as the Nur's delivery grows more animated, she attracts the attention of the entire group (see laughter in line 34). Note that Arabic code switches that are transliterated within the text of this article are bolded and transcribed phonetically in this and the following transcripts:

\section{Excerpt 1}

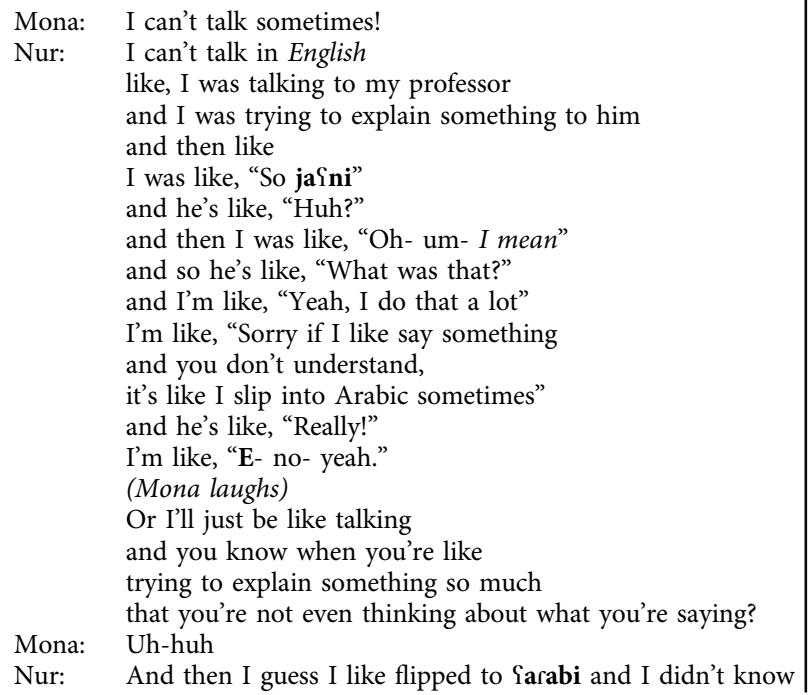

23

24

25

26

27

28
29

30

31

32

33

34

35

36

37

38

39

40

41

42
43

43

44
It was like- just weird cuz he's totally American, and-

Nerine: Who were you talking to?

Nur: I said [jaini] to a professor and he's like, "Huh?" and then I was-

Nerine: I say [alhamdulilæ] to everybody.

Nur: Oh! (slaps the table with the flat of her hand) I said [Infa ala]!

My TA, she's like, "You'll do good."

I'm like, "[Infa ala]!"

And she's like, "What?"

And I'm like, "Uh-oh."

(The entire group is laughing now)

She's like, (high pitched) "What is that?"

And I'm like, "That means hopefully."

She's like, (high pitched) "What language?"

And I'm like, "Oh, God, here we go.

I have to like give a whole history class."

Mona: Chinese!

Nerine: In- in [Iraki]! Like Lebanese.

Nur: No, I'm like, "Arabic."

She's like, "Oh, are you from Saudi Arabia?"

I'm like, "No, from [Irak]."

Nur's response to her teaching assistant (TA) in lines 38-39 speaks to the frequency with which members of the halaqa found themselves asked to explain their backgrounds. The tongue-incheek suggestions from Mona and Nerine (lines 40-41) point to their familiarity with such queries and their expectation of outsiders' exoticizing misinformation and/or misunderstanding of Arab national and linguistic distinctions. The fact that Nur's initial embarrassment is set off by her use of the ubiquitous and entirely mundane Arabic discourse marker, y'ani ([jaini], I mean) is telling in terms of the degree to which these women felt they needed to monitor their linguistic performances in public. As members of a widely surveilled minority group, even benign requests and expressions of genuine interest such as those from Nur's instructors could carry the hint of suspicion and the implicit demand to make oneself legible to members of the dominant society. As Hill (2008) has discussed, such moments are also driven by an ideology of monoglot standard speech, which holds that any language or variety other than "mainstream" American English is subject to special scrutiny.

Still, it is important to point out that women in the halaqa were quite active in educating the campus and public about Islam and culture in Muslim countries. As members of the Muslim Student Association, they sat on panels and organized information booths during Islamic Awareness Week, often in charge of covering the topics of gender equality and hijab. They gave interviews to the student newspaper during Ramadan and modeled efforts by the larger Desert Masjid community to reach out to non-Muslims. The mosque itself hosted open houses, curated public relations videos, talked to local media outlets, and otherwise strove for an image of transparency and openness.

I learned at the beginning of my research that such efforts belied a modicum of resentment for some. Early in my fieldwork, I would circulate around the women's area of the mosque before halaqa meetings, chatting with research participants and their relatives. As I met new people, I explained my project, which I characterized as broadly focusing on local Muslim American women's everyday realities. Upon moving away from a small cluster of older women one night, I heard one of them remark, "Let them ask all the questions they want! I don't have a problem with it. What do they think they'll find?!" I understood that the comment was meant for me, and it dawned on me that for these women, even my genuine desire to build rapport carried the possibility of betrayal. For a collective doing its best to dissuade suspicion, even well-meaning attention from non-Muslims 
occasioned guardedness. Indeed, fatigue and frustration came with being a source of both curiosity and mistrust. And there was good reason: the building that housed Desert Masjid had been tagged with graffitied epithets, and residents from the surrounding apartment buildings and fraternity houses occasionally threw trash onto the mosque grounds. Too, with some families having fled civil war and lost loved ones to violence in places like Iraq circumspection was understandable.

Within this context, Mona, Nur and Nerine's exchange about "slips" into Arabic pointed to a concern with hypervisibility but also with authenticity and solidarity. By their telling, moments of presumed disfluency in English were unintentional and therefore deeply interiorized, expressed instinctively through utterances such as y'ani and insha allah. Lack of intentionality signaled an essentialized but transnational Arab Muslim identity that preceded in biographical time their arrival on campus and connected them to far-flung heritage cultures-prompting, for instance, Nur's complaint that she would have to give "like [...] a whole history class" to explain herself to her instructor. Narration provided discursive resolution to social discomfort as the women colluded in normalizing moments of unwitting exposure and remedying them by voicing interior dialogue or offering commiserating laughter. By the same token, this narrating event highlighted an implicit ethical stance that made vigilance and selfmonitoring crucial to avoiding future embarrassment. The subject positions unfolding collaboratively in the transcript above cannot avoid Muslim hypervisibility (perhaps especially as women who wear hijab) but must also remain keen to outsiders' perceptions to successfully manage, rather than encourage, scrutiny.

Still, halaqa attendees devoted regular attention to examining their own ethno-racial and linguistic differences, as well, suggesting that such distinctions were part of how they made sense of the world and built connections. In this way, their moral world-making operationalized indexes of phenotypic and linguistic legitimacy that are commonly negotiated in struggles over identity and belonging, while also making claims as to whose vision of those distinctions held sway.

\section{Using phonology to debate phenotype}

Core participants referred to themselves and each other according to their families' places of origin: Sara and Tara were Pakistani; Layla was Libyan; Mona, Egyptian; and Zeinab, Ibtisam and Nur were Iraqi. Peripheral members used a similar practice, referring to themselves by heritage nationalities. And in an uncharacteristic move for members of dominant U.S. society, even Dana, a convert, regularly called herself a "white American". Such attention to ethno-cultural and racial distinctions indicates awareness of how these classifications mapped onto broader structures of power and privilege. Participants' control over and claims to membership within this structure became the focus of debate one night when Dana herself ventured that Nerine looked more like her Lebanese dad, and more "Arab," than her younger sister, Lulu.

"No, it's cuz she's wearing eyeliner and I'm not," Lulu immediately countered, referencing an unmistakable index of Arab ethno-racial difference: darkness (and perceived exoticness) of the eyes.

"Otherwise you'd look really the same," Dana tried again.

"Absolutely not!" Zeinab exclaimed. There was a chorus of "No"s from others in the group, and all eyes turned from Nerine to Lulu and back again.

"Really?" Dana asked, looking surprised, "I thought Lulu looked more like their [Euro-American] mom."

Nerine laughed, "You're the first person I think who's ever said that!"
Participants continued to challenge Dana's aesthetic instincts, using markers of ethno-racial classification, and ultimately phonological distinction, to make their points. Contrasting articulations of "Arab" and "hijab" are rendered phonetically in the transcript of the exchange, and I argue their significance below.

\section{Excerpt 2}

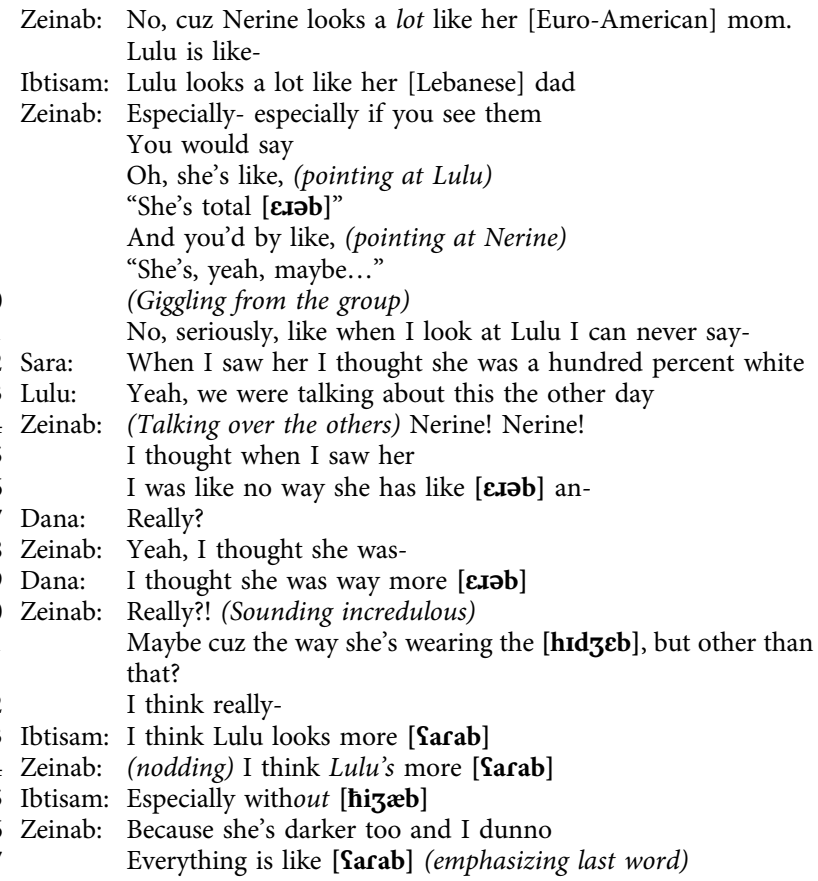

In line 12, Sara leverages Zeinab's claim that she sees Lulu as "total Arab" (line 7) to assert that Nerine, by contrast, looks "one hundred percent white." In this, she draws a racializing contrast between categories of Arabness and whiteness that Zeinab follows up with a suggestion that perhaps it was how Nerine wore her headscarf that prompted Dana's misinterpretation (line 21). Here, assertions of ethno-racial difference come together with recognition of the hijab as a religious marker of difference in a nonMuslim context.

Most striking, however, is that Ibtisam in line 23 prompts a phonological shift that Zeinab echoes, rendering the words "Arab" and "hijab" as signposts for their claim to aesthetic authority and expertise in reading signs of difference. Because English and Arabic phonologies diverge-particularly when it comes to the voiced pharyngeal fricative [个]- such moves demarcate cultural authority through linguistic performance. But their expertise could only have been born of embodied connections to their heritage language and repeated encounters with outside scrutiny, whether well meaning or not (see "Linguistic Exposure," above). That is, to accurately name one's difference was also to guard against undue exposure or misunderstanding. Dana, who had grown up in an Englishspeaking family, did not wear the hijab outside the mosque, and until a few years ago lived as a secular white American, could not fully share these phronetic sensibilities. She understood this reflexive vigilance intellectually-and she expressed great concern over Islamophobia during an interview-but not experientially.

To be experientially wise to the social mechanics of otherness and ready to deploy or defuse affirmations of distinction was at the heart of halaqa phronesis. If phronesis concerns the powerand value-laden "preconditions of actual discourse" and action (Flyvbjerg, 2001: 96), then these data illustrate how halaqa 
participants sought ways of caring for themselves and others by asserting intimate knowledge of the multiple terms by which belonging and exclusion occurred in their lives.

Perhaps for this reason, Sara took special exception to how her own father introduced her and her younger sister, Tara, to new people. Similarly to Dana, he lacked the unique phronetic awareness that came with being a second-generation mediator of cultural difference, and so his attempts to normalize his family's presence within a majority white American context often failed. As Sara recounted one night to Layla and me, he had a tendency to Anglicize his daughters' names. Rather than pronouncing them using his native Pakistani Urdu phonology, he overcorrected in trying to make them sound more "American." I note these distinctions by using phonetic transcription in bold as follows:

\section{Excerpt 3}

\begin{tabular}{|c|c|c|}
\hline $\begin{array}{l}1 \\
2\end{array}$ & Sara: & 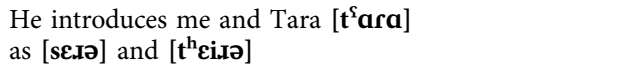 \\
\hline 3 & Maisa: & 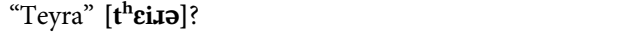 \\
\hline 4 & Sara: & I’m like, "No! Don't say that!" \\
\hline 5 & & He's like- to white people? \\
\hline 6 & & He'll be like- Americans? \\
\hline 7 & & 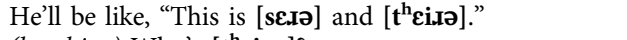 \\
\hline 8 & Layla: & 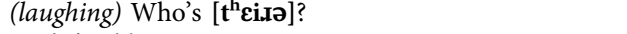 \\
\hline 9 & Sara: & And I'm like- \\
\hline 10 & & 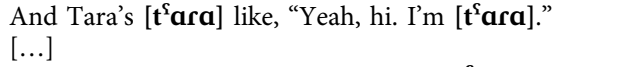 \\
\hline 11 & & A lot of people have a hard time with [ $\left.\mathbf{t}^{\mathrm{s}} \mathbf{a r a}\right]$ \\
\hline 12 & & {$\left[\mathbf{t}^{\mathrm{S}} \mathbf{a r a}\right]$ with a $\left[\mathbf{t}^{\mathrm{S}} \mathbf{a}\right]-\left[\mathbf{t}^{\mathrm{S}}\right]-$} \\
\hline 13 & & So when you say [ $\mathbf{t}^{\mathbf{s}} \mathbf{a r a}$ ] they're like, \\
\hline 14 & & "How are you doing that? [ $\left.{ }^{\mathrm{h}} \mathbf{\varepsilon} \mathbf{I} ə\right]$ ? \\
\hline 15 & & 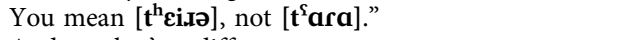 \\
\hline 16 & & And so, that's a different name, \\
\hline 17 & & But people don't know that. \\
\hline 18 & & People're just like, “[se.ıə] or [sara]?” \\
\hline 19 & & I'm like, “I don’t care.” \\
\hline 20 & & And they're like, "What do you mean you don't care?" \\
\hline 21 & & But they're different, \\
\hline 22 & & and they don't know that, so. \\
\hline
\end{tabular}

By Sara's telling, the replacing of emphatic Urdu consonants and flapped alveolar [r] with aspirated English consonants and rhotic [I] demands correction. Interestingly, her story highlights not only her father's perplexing Anglicization of his daughters' names, but also other people's insistence and attempts to correct her pronunciation in turn (lines 13-15).

In this way, the objectification of linguistic tokens, down to the level of individual phonemes, provided micro-stages upon which self-reflexive monitoring and responses to outside scrutiny played out. Insofar as core halaqa members expressed keen meta-linguistic awareness through such objectification, their narrated responses also pointed to a tendency to deflect unwanted outside attentionfrom teachers or, here, new acquaintances-through ambivalent but disarming stances. For Nur, in Excerpt 1, this included embarrassed apprehension (“And I'm like, 'Uh-oh'” (line 33)) and good-natured resignation ("And I'm like, 'Oh, God, here we go'" (line 38)). For Sara, above, it meant professed indifference ("I'm like, 'I don't care" (line 19)) and a retreat into her own experiential knowledge when the task of normalization presented too direct a challenge to dominant perspectives ("But [the names] are different, and they don't know that, so" (lines 21-22)).

In such ways, core halaqa members acknowledged the difference cued by their presence in a non-Muslim, dominantly white and English-speaking surround. I posit that in telling these stories and holding these impromptu debates, they indirectly articulated the means by which they had learned to assess and judiciously contain their own conspicuousness in the public sphere. One last data excerpt will clarify this point as I consider one of Sara's popular and extended narratives about her father.

\section{Mock accent and narrative mediation}

"I just make it up". That was Sara's response when one of her friends at the halaqa asked how she had learned to imitate her father's Pakistani-Urdu accented English. Among the young women who gathered for weekly meetings, accented revoicings of fathers' speech constituted a recurring conversational tool. Nerine did a somber and warm interpretation of her father's Arabic accented English. Layla, also in an affected Arabic accent, imitated her father trying to talk to her about her crush on a young man. But Sara's performances elicited uproarious laughter, not least of all because they involved cathartic processing of attendees' own politically charged identities. Narrated years after September 11, Sara's story evoked both the anxiety and absurdity of her father's all-too-conspicuous attempts to express patriotic loyalty.

As narrating and narrated mediator, Sara positioned herself as witness to his faux pas, and as she began her story, she framed it in explicitly racialized terms. Several days after the terrorist attacks, she explained, her dad went to the hospital where he worked wearing an American flag pin on his lapel. "Like- a brown man," she said, giggling. "And we don't have our immigration yet, ok? So we need to suck up as much as possible!" The other women in the room giggled, too; Sara was warming up, a broad smile played across her face and her eyes twinkled. She was a natural comic who juxtaposed the real pathos of political vulnerability with benign violations of social norms and expectations (Humor Research Lab, 2015). That a "brown" (that is, South Asian) man who was not yet a citizen might sport a flag pin-an emblem of right-leaning conservative sympathies, moreover-was one such irony.

But Sara went on to relate that when visiting New York City she had earlier purchased a gaudy tie as a joke for her father, "like, with American flags all over it, and the Twin Towers". To her shock and bewilderment, he wore that tie to work, as well. Her narrative continued as follows. Sara's imitation of her father's accented speech appears phonetically transcribed under lines 8-12:

\section{Excerpt 4}

\begin{tabular}{|c|c|c|}
\hline 1 & Sara: & I did not think- \\
\hline 2 & & I thought it would be a joke! \\
\hline 3 & & So, I was like, "Dad? \\
\hline 4 & & You can't wear \\
\hline 5 & & the American flag with the Twin Towers to work- \\
\hline 6 & & the tie." \\
\hline 7 & & (.) \\
\hline 8 & & $\begin{array}{l}\text { "I really feel like } \\
{\left[\mathbf{e}^{\mathbf{i}} \text { [Ili fiil le } \mathbf{l}^{\mathbf{i}} \mathbf{k}\right]}\end{array}$ \\
\hline 9 & & $\begin{array}{l}\text { there's a lot of respect } \\
\text { [ders e lot } 2 \mathbf{v} \text { [Ispect] }\end{array}$ \\
\hline 10 & & $\begin{array}{l}\text { that has happened after I wore this, you know. } \\
\text { [det hes hepend eftor } \mathbf{e}^{\mathbf{i}} \text { vor dis, iu no] }\end{array}$ \\
\hline 11 & & $\begin{array}{l}\text { The white American doctors } \\
\text { [di ve } \mathbf{e}^{\mathbf{i}} \mathbf{t} \text { əmertkın dukters] }\end{array}$ \\
\hline 12 & & $\begin{array}{l}\text { are really comfortable with me." } \\
\text { [er rili kəmftərbl wid mi] }\end{array}$ \\
\hline 13 & & (.) \\
\hline 14 & & “They're afRAID OF YOU!” \\
\hline 15 & & (Peals of laughter from those present) \\
\hline 16 & & “They don't wanna make you angry!” \\
\hline 17 & & (Giggling continues) \\
\hline 18 & & So, (.) I don't know if he wears it anymore, \\
\hline 19 & & but he wore it like two, three times. \\
\hline 20 & & And his secretary, who's white- an American, is like, \\
\hline
\end{tabular}


"You need to tell him to stop wearing that." I was like, "I- I noticed!"

[...] It's just weird.

He's like a brown man,

and like- it's so weird.
Sara herself, unlike the other figures in the narrative, stands at a political, linguistic, and generational intersection. She is the one her father's secretary appeals to (line 21). She is the one her father confides in (lines 8-12). She is also a masterful reader of the social-semiotic signs in play, whose ironic gift of a tie helps escalate her father's faux pas. He, evidently, does not know how to interpret these signs in tandem.

But it is in Sara's telling of this story to a group of like-minded listeners-in the narrating, more than narrated, event (Wortham and Reyes, 2015) - that she models phronetic virtue. First, she renders her father through an infelicitous bundling of signs (Keane, 2005), including extravagant symbols of patriotism, racial markedness (as "a brown man"), and linguistic foreignness. These, with his naive optimism, create the image of a man who is overcorrecting, trying too hard, or in any case making a bumbling attempt to fit in. Second, Sara is not only savvy enough to read these signs and understand their implications, but she is also able to take distance from both sides in this struggle. Her use of mock accent deterritorializes her father's identity, positioning her by contrast as less racialized and more normatively American, her citizenship status notwithstanding. At the same time, there is inherent critique in her recognition that American Islamophobia has become a racialized phenomenon affecting people like her father, whose good intentions can be mistaken for threats. Given that families across the U.S. faced detention under the USA PATRIOT Act (Bayoumi, 2008), and "brown" men and women have become increasing targets of hate crimes, Sara's attention to racial positioning is a move of concern and a rejection of dominant colorblind ideologies, which proclaim racism to be over.

Finally, Sara's comedic delivery and successful elicitation of laughter from the other halaqa attendees disarms the tension created around her father's actions. While the situation remains unresolved in the narrated event-Sara ends her story with the ambivalent, "It's just weird [...] it's so weird" (lines 23 and 25)the narrating event allows for collaborative discursive action such that the struggle of otherness becomes shared and its burden lightened through humor. Narrator and audience are allowed to occupy ethical positions on the other side of "weird," wise to their own sociopolitical vulnerability but also to the unwitting foibles of those who, like Sara's father, are naive about the promise of American inclusion. Therein lies halaqa participants' enactment of virtue beyond the purview of religious teachings, elaborated through recognition of that dual imperative of politicized selfmonitoring and defusing the perceived "Muslim threat".

Fathers' mock accents constituted sites of mediation between Muslim and non-Muslim subjectivities, and daughters acted as the linguistic arbiters of those sites. They used mock accent in reported speech first to claim intimate knowledge of their paternal heritages. Being able to recreate how their fathers sounded allowed them also to lay claim to a privileged sphere of cultural practices that extended to ideologies of gender norms, dress, food and entertainment in places such as Pakistan, Iraq, or Lebanon. These young women balanced appeals to subjectivities based on exclusive kinship ties abroad with expert knowledge of non-Muslim American culture, however. This knowledge turned their use of mock accent into a commentary upon their fathers' foreignness even as it used that foreignness as a mark of personal distinction and virtuous mediation.
Chun (2004) maintains that even "legitimate" mockery"performing the speech of a racialized other who is not necessarily a racial other" (p. 264, emphasis in the original)-contributes to racial othering. Because in-group mockery avails itself of linguistic stereotypes, this creates ambivalence for speakers as they align themselves both with and against the dominant ideologies that inspire those stereotypes. In mediations like Sara's, the narrator's objectification of foreign accented English, accompanied by "unaccented" metacommentary, establishes the discursive vantage point from which mock accent both instantiates distinction and remains circumscribed by dominant speech norms. Following Chun, mock accent instantiates spatial and temporal distance between Sara's father (projecting him "back" to Pakistan), "white Americans" and Sara herself, who stands apart from both as an incisive witness and disarming narrator.

\section{Concluding remarks}

The phronetic sensibilities and subject positions cultivated through informal halaqa talk revolved around the social acumen of second-generation Muslim American women who had to navigate everyday life in a context that presupposed and scrutinized their difference while often demanding a judicious, measured response. As shown throughout this article, defusing cultural misencounters meant playing the role of intercultural mediator or at least being an experientially informed witness and interpreter of events.

Unlike the participants in Mir's (2014) study of Muslim American women on east coast college campuses-who seemed to carry untenable burdens of social stigma and scrutiny-halaqa attendees in the southwest used storytelling and dialogue to recast moments of cultural tension and embarrassment as opportunities to exercise phronetic virtue. I find that the young women engaged in halaqa talk illustrated collaborative and multi-faceted efficacy, even if delimited by out-group perceptions.

I argued that halaqa subjectivity was forged at those points where contrasts between American and Muslim, Arab/brown and white, and English and non-English proficiencies met. Core participants marked these boundaries linguistically through tactics of linguistic objectification, using codeswitching, foreign phonologies, non-native accented English, and linguistic metacommentary to highlight capacities for bearing the burden of hypervisibility as well as normalizing difference. This was especially salient where speakers sought to correct the assertions or performances of others who lacked their experience and perspectival nuance.

I have introduced the analysis of very small discursive features and tactics into consideration as phronetic anchor points. Whereas the indexical qualities of linguistic forms continue to be productively analyzed within ethnographic studies of discourse and ideology, it will be fruitful to explore the potential for understanding people's situational positioning and value-driven actions in light of the particular linguistic "micro-practices" available. Such an approach connects discourse in the abstract with action (that is, communication) in the concrete. It also deepens phronetic inquiry by reaching down into the smallest of socially meaningful "little things" (Eubanks, 2012) to examine their connections and contextual importance to larger, more evident power relations.

Indeed, phronesis itself does not entail strict duality between lofty ideals and in-the-world action or between imposed norms and free agency (Jouili, 2015). Instead, it allows for understanding how people live their subjectivity through a series of minute instances of aesthetic vigilance, ethical ambivalence, struggle and uncertainty, particularly when "doing the right thing" is defined in contrasting ways or constrained by one's position within a 
social hierarchy. Informal halaqa conversations showed how speakers monitored and shared strategies for managing Muslim hypervisibility. Narratives and laughter endorsed subject positions wrought through long-term familiarity with difference, understood both from the inside and the outside. In this, core participants' savvy negotiation of linguistic, generational, and ethno-racial/-religious conspicuousness suggested unique experiential insight and the inclination to serve the greater good by defusing, but not denying, the identitarian tensions that have become part and parcel of Muslim Americans' daily lives.

\section{References}

Agha A (2007) Language and Social Relations. Cambridge University Press: New York.

Ahmed L (1992) Women and Gender in Islam. Yale University Press: New Haven, CT.

Alim HS (2016) Introducing raciolinguistics: Racing language and languaging race in hyperracial times. In: Alim HS, Rickford JR and Ball AF (eds). Raciolinguistics: How Language Shapes our Ideas About Race. Oxford University Press: Oxford, pp 1-30.

Angermuller J (2013) How to become an academic philosopher: Academic discourse as multileveled positioning practice. Sociología Histórica; 2, 263-289.

Atkinson JM and Heritage J (eds) (1984) Structures of Social Action: Studies in Conversation Analysis. Cambridge University Press: Cambridge, UK.

Bayoumi M (2008) How Does it Feel to be a Problem?: Being Young and Arab in America. Penguin: New York.

Bucholtz M (2011) White Kids: Language, Race, and Styles of Youth Identity. Cambridge University Press: New York.

Chun EW (2004) Ideologies of legitimate mockery: Margaret Cho's revoicings of mock Asian. Pragmatics; 14 (2/3): 263-289.

Eckert P (1989) Jocks and Burnouts: Social Categories and Identity in the High School. Teachers College Press: New York.

Eckert P, McConnell-Ginet S (1992) Communities of practice: Where language, gender, and power all live. In: Hall K, Bucholtz $\mathrm{M}$ and Moonwoman B (eds). Locating Power: Proceedings of the 1992 Berkeley Women and Language Conference. Berkeley Women and Language Group: Berkeley, CA, pp 89-99.

Eubanks V (2012) Feminist phronesis and technologies of citizenship. In: Flyvbjerg B, Landman T and Schram S (eds). Real Social Science: Applied Phronesis. Cambridge University Press: New York, pp 228-245.

Fader A (2009) Mitzvah Girls: Bringing up the Next Generation of Hasidic Jews in Brooklyn. Princeton University Press: Princeton, NJ.

Flyvbjerg B (2001) Making Social Science Matter: Why Social Inquiry Fails and How it Can Succeed Again. Cambridge University Press: Cambridge, UK.

Flyvbjerg B, Landman T and Schram S (eds) (2012) Real Social Science: Applied Phronesis. Cambridge University Press: New York.

Foucault M (1972) The Archaeology of Knowledge and the Discourse on Language. Pantheon Books: New York.

García-Sánchez IM (2015) Language and Muslim Immigrant Childhoods: The Politics of Belonging. Wiley Blackwell: Malden, MA.

Gaudio RP (2009) Allah Made Us: Sexual Outlaws in an Islamic African City. Wiley Blackwell: Malden, MA.

González N (2005) I Am my Language: Discourses of Women and Children in the Borderlands. University of Arizona Press: Tucson, AZ.

Goodale M (2012) Human rights. In: Fassin D (ed). A Companion to Moral Anthropology. Wiley Blackwell: Malden, MA, pp 468-481.

Goodman AH, Moses YT and Jones JL (eds) (2012) Race: Are we so Different? Wiley Blackwell: Malden, MA.

Goodwin MH (2006) The Hidden Life of Girls: Games of Stance, Status, and Exclusion. Blackwell: Malden, MA.

Hammer J (2012) American Muslim Women, Religious Authority, and Activism: More Than a Prayer. University of Texas Press: Austin, TX.

Hill JH (1993) Hasta la vista, baby: Anglo Spanish in the American Southwest. Critique of Anthropology; 13 (2): 145-176.

Hill JH (1995) The voices of Don Gabriel: Responsibility and self in a modern Mexicano narrative. In: Tedlock D and Mannheim B (eds). The Dialogic Emergence of Culture. University of Illinois Press: Urbana, Chicago, IL, pp $97-147$.

Hill JH (2008) The Everyday Language of White Racism. Wiley Blackwell: Malden, MA.
Humor Research Lab. (2015) Benign violation theory. [Online], http://leedsfaculty.colorado.edu/mcgrawp/Benign_Violation_Theory.html, accessed 23 October 2016

Jouili JS (2015) Pious Practice and Secular Constraints: Women in the Islamic Revival in Europe. Stanford University Press: Stanford, CA.

Keane W (2005) Signs are not the garb of meaning: On the social analysis of material things. In: Miller D (ed). Materiality. Duke University Press: Durham, NC, pp 182-205.

Lippi-Green R (2012) English with an Accent: Language, Ideology, and Discrimination in the United States, 2nd ed., Routledge: Abingdon, Oxon, UK.

Mahmood S (2005) Politics of Piety: The Islamic Revival and the Feminist Subject. Princeton University Press: Princeton, NJ.

Mendoza-Denton N (2008) Homegirls: Language and Cultural Practice Among Latina Youth Gangs. Blackwell: Malden, MA.

Mendoza-Denton N (2016) Norteño and Sureño gangs, hip hop, and ethnicity on YouTube. In: Alim HS, Rickford JR and Ball AF (eds). Raciolinguistics: How Language Shapes our Ideas About Race. Oxford University Press: Oxford, pp $135-150$.

Mir S (2014) Muslim American Women on Campus: Undergraduate Social Life and Identity. The University of North Carolina Press: Chapel Hill, NC.

Nafisi A (2003) Reading Lolita in Tehran. Random House: New York.

NPR Staff. (2015) Faced with fear, a Muslim woman makes a stand-by setting one up. NPR Weekend Edition Sunday [Online] 27 December, http://www.npr.org/ 2015/12/27/461124403/faced-with-fear-a-muslim-woman-makes-a-stand-bysetting-one-up, accessed 25 January 2017.

Ronkin M and Karn HE (1999) Mock ebonics: Linguistic racism in parodies of Ebonics on the internet. Journal of Sociolinguistics; 3 (3): 360-380.

Satrapi M (2003) Persepolis: The story of a Childhood. L'Association: Paris, France. Silverstein M (1976) Shifters, linguistic categories, and cultural description. In Basso K and Selby H (eds). Meaning in Anthropology. University of New Mexico Press: Albuquerque, NM, pp 11-55.

Tetreault C (2015) Transcultural Teens: Performing Youth Identities in French Cités. Wiley Blackwell: Malden, MA.

Wang Y (2014) Between Islam and the American Dream: An Immigrant Muslim Community in post-9/11 America. Rutledge: New York and London.

Welji HN (2012) Adding Allah to alhamdulilah: The use of Arabic God-phrases for performative functions. M.A. Thesis, University of California San Diego.

Wortham S and Reyes A (2015) Discourse Analysis Beyond the Speech Event. Routledge: London and New York.

Zentella AC (1997) Growing up Bilingual: Puerto Rican Children in New York Blackwell: Malden, MA.

\section{Data availability}

Data sharing is not applicable to this article as no datasets were analysed or generated.

\section{Acknowledgements}

The author wishes to thank the women who participated in this research, along with Jen Roth-Gordon, Norma Mendoza-Denton, Rudi Gaudio, Ashley Stinnett and Sarah Trainer for their input on early incarnations of this analysis.

\section{Additional information}

Competing interests: The author declares that there are no competing financial interests

Reprints and permission information is available at http://www.palgrave-journals.com/ pal/authors/rights_and_permissions.html

How to cite this article: Taha MC (2017) Discourse as virtue ethics: Muslim women in the American Southwest. Palgrave Communications. 3:17026 doi: 10.1057/palcomms.2017.26.

Publisher's note: Springer Nature remains neutral with regard to jurisdictional claims in published maps and institutional affiliations.

This work is licensed under a Creative Commons Attribution 4.0 International License. The images or other third party material in this article are included in the article's Creative Commons license, unless indicated otherwise in the credit line; if the material is not included under the Creative Commons license, users will need to obtain permission from the license holder to reproduce the material. To view a copy of this license, visit http://creativecommons.org/licenses/by/4.0/ 